62. Shkvarets, V. Nimtsi pivdennoho rehionu suchasnoi ukrainskoi derzhavy [Germans of the southern region of the modern Ukrainian state]. URL: www.nbuv.gov.uaportalSoc_GumNvmduIst...3...shkvarets.pdf [in Ukrainian].

63. Shcharbak, Yu. (2017). Ukraina v epitsentri svitovoho shtormu: otsinky, prohnozy, komentari [Ukraine in the epicenter of the world storm: estimates, forecasts, comments]. Kyiv. Yaroslaviv Val. 163-164; 211 [in Ukrainian].

64. Shcherba, O. (2012). Krymskotatarska spilnota yak sub'iekt polityky: teoretychnyi aspekt [The Crimean Tatar community as a subject of politics: a theoretical aspect]. Ukrainska natsionalna ideia: realii ta perspektyvy rozvytku [The Ukrainian National Idea: Realities and Prospects for Development]. 24. 138-143 [in Ukrainian].

Одержано 23.05.2019.

УДК 94:[378.147:621.313-051](477) «192»

\author{
Аннснков Ігор, \\ кандидат історичних наук, докторант \\ goalan93@gmail.com \\ http://orcid.org/0000-0002-6642-8048 \\ Національна наукова сільськогосподарська \\ бібліотека Національної академії аграрних \\ наук України, \\ вул. Героїв Оборони, 10, м. Київ, Україна, \\ 03127
}

\section{DOI https://doi.org/10.31470/2415-3567- 2019-46-250-256}

\author{
Annenkov Igor, \\ Candidate of Historical Sciences, \\ doctoral student \\ goalan93@gmail.com \\ http://orcid.org/0000-0002-6642-8048 \\ National Scientific Agricultural Library of the \\ National Academy of Agrarian Sciences of \\ Ukraine, \\ 10, Heroiv Oborony, Kyiv, Ukraine, 03127
}

\title{
ОСОБЛИВОСТІ УМОВ ПІДГОТОВКИ НАУКОВО-ТЕХНІЧНИХ КАДРІВ ДЛЯ УКРАЇНСЬКОГО ЕЛЕКТРОМАШИНОБУДУВАННЯ В 1920-Х РР.
}

Метою даної статті є визначення основних особливостей умов підготовки науково-технічних кадрів для електромашинобудівної сфери УСРР. За допомогою порівняльно-історичного, діахронічного і синхронічного методів вивчено вплив упродовж 1920-х рр. характеру функціонування українського електромашинобудування в складі єдиного народногосподарського комплексу СРСР на умови підготовки науково-технічних кадрів для иієї галузі. Встановлено, що первісне украӥнський електромашинобудівний сектор не розглядався союзним урядом як одна з рушійних сил розпочатих ним прочесів індустріалізації та електрифікації країни. Причиною изьому стали як брак в украӥнських підприємств власного наукового супроводу виробництва сучасних електричних машин, так $і$ відсутність можливості здійснювати таке забезпечення існуючими в республіці непромисловими профільними науково-технічними підрозділами. При тому розпочався прочес закриття ичих підприємств, який утім не знайтов свого завершення, оскільки в середині 1920-х рр. був зупинений. 3'ясовано, шзо в ией час у Харкові фундується великий осередок виробництва військово-морської електротехніки на основі конструкиій та технологій, наданих німеиькою електротехнічною фірмою «АЕГ». Підставою для изього, в першу чергу, став досвід "АЕГ» у такого роду співробітниитві з Російською імперією напередодні І Світової війни, а також те, щуо підчас иієї війни відповідне устаткування вироблялося на Харківському заводі згаданого конщерну, в наступному в нього секвестрованому. 3 певною затримкою в півтори-два роки, там же був організований 
масовий випуск електричних машин иивільного виконання, виготовлення яких також здійснювалося за технічною документачією «АЕГ». Таким чином, у місті почала стрімко зростати потреба на профільні науково-технічні кадри, щуо стало причиною подальшоі конщентрації підготовки таких фахівців саме в Харкові, у місиевому Технологічному інституті. Разом із указаним раніше, визначено, щз загальний рівень надаваних «АЕГ» та іншими зарубіжними фірмами профільних знань перевищував наявний в українських вищих технічних навчальних закладах, щуо стало головною особливістю умов підготовки в УСРР науково-технічних кадрів для республіканського електромашинобудування впродовж 1920-х рр.

Ключові слова: промисловість, електрифікація, індустріалізачія, науково-технічні кадри, електромашинобудування, військово-морська електротехніка, науковий супровід.

\section{FEATURES OF THE CONDITIONS FOR THE TRAINING OF SCIENTIFIC ENGINEERING PERSONNEL FOR UKRAINIAN ELECTRIC MACHINERY INDUSTRY IN THE 1920S}

The purpose of this article is to determine the main features of the conditions for the preparation of scientific engineering personnel for Ukrainian electric machinery industry in the 1920s. Using comparative historical, diachronous and synchronous methods, the influence of the functioning of Ukrainian electric machine building as a part of the national economic complex of the USSR in the 1920s on the conditions for the training of scientific and technical personnel for this industry was studied. It is established that initially the Ukrainian electric machine building was not considered by the union government as one of the driving forces of the processes of industrialization and electrification of the country that he started. The reason for this was both the lack of scientific support in the production of modern electric machines at the Ukrainian enterprises themselves, and the lack of the ability to receive it from non-industrial specialized scientific engineering units that existed in the republic. At the same time, the process of closing these enterprises began, which, however, could not be completed, since it was stopped in the mid-1920s. It was determined that at that time a large center for the production of naval electrical equipment was organized in Kharkov based on designs and technologies provided by the German electrical company AEG. The reason for this was, first of all, the experience of AEG in this kind of cooperation with Russia on the eve of the First World War, as well as the fact that during this war the corresponding equipment was produced at the Kharkov plant of this concern, which was subsequently sequestered. With a slight delay of one and a half to two years, mass production of civilian electric machines is immediately organized, the manufacture of which is also carried out according to the AEG technical documentation. Thus, the need for specialized scientific engineering personnel began to increase rapidly in the city, which caused the subsequent concentration of training of such specialists in Kharkov, at the local technological institute. Together with the aforementioned, it was determined that the general level of specialized knowledge provided by AEG and other foreign firms exceeded the existing level in Ukrainian higher technical educational institutions, which became the main feature of the conditions for the training of scientific engineering personnel in the Ukrainian SSR for the republican electric machine building during the 1920s.

Key words: industry, electrification, industrialization, scientific engineering personnel, electrical engineering, naval electrical engineering, scientific support.

1920-і рр. знаменні в історії промисловості України переходом від викликаного революційними подіями та громадянською війною на іï теренах паралічу виробничої діяльності на початку цього десятиліття до поновлення процесу індустріалізації наприкінці. Одночасно, в УСРР розгорталися заходи з електрифікації промисловості, що дозволяло значно пришвидшити індустріалізацію за рахунок широкого використання більш досконалих машин, оснащених індивідуальним електроприводом i, як наслідок, 
кількаразово підняти продуктивність праці, знизивши споживання енергоресурсів на одиницю співставних виробів. Відповідно означеному, роль електромашинобудівної галузі як сфери створення засобів прискорення індустріалізаційних процесів, у другій половині 1920-х років набула величезної значущості, а ії науково-технічний розвиток мав проходити випереджаючими темпами. Між тим, провідниками цього розвитку в промисловості $€$ науково-технічні працівники, від яких прямо залежить ступінь як запроваджуваної у виробництво, так і отримуваної у виробленій продукції науковотехнічної новизни, а також рівень якості та надійності продукції. Тож питання забезпечення вітчизняного електромашинобудування науково-технічними кадрами (НТК) впродовж 1920-х рр. мало визначальний характер для всієї ходи процесу індустріалізації. Таким чином, вивчення умов, в яких відбувалося забезпечення досліджуваної галузі НТК в обраний хронологічний період дозволяє отримати знання стосовно впливу, через кадрову складову потенціалу визначальних, на певному етапі науково-технічного розвитку, секторів промисловості, дискретних відтинків індустріального регресу на ступені спроможності відновлення наступного прогресивного руху, що й робить дану історичну розвідку актуальною.

У нечисленній радянській історіографіï стосовно як союзного, так й українського електромашинобудування аспект підготовки НТК, фактично, не розглядається, навіть якщо за змістом наявність таких відомостей у ній передбачається. Так, у другому томі: «Электротехника» [1] тритомного видання: «История энергетической техники СССР» анонсується підрозділ 12-6: «Научные исследования и подготовка кадров в области электрических машин», але за підготовку науково-технічних кадрів у цьому підрозділі не йдеться. Також відсутня інформація стосовно піднятого в цій статті питання в монографії, присвяченій історії найбільшого в Україні електромашинобудівного підприємства Харківського електромеханічного заводу (ХЕМЗ), хоч у підрозділі: «Каждый цех кузница кадров» присутні певні відомості щодо заводських НТК, але лише 1930-х рр. У nострадянській історіографіï розвитку електротехніки на українських теренах питанню підготовки галузевих НТК присвячені наукові праці О.С. Тверитникової, але як у іiі дисертаційному дослідженні [3], так і в публікації [4] електромашинобудівна сфера 3 електротехнічної не виділяється i, при цьому, період 1920-х pр. розглянутий дуже побіжно та поверхнево. Отже, тема даної статті на сьогодні є недослідженою. Метою історичної розвідки $є$ визначення головних особливостей умов підготовки НТК для українського електромашинобудування впродовж 1920-х рр., що передбачає вирішення $\underline{\boldsymbol{3 a b d a \boldsymbol { b }}} 3$ виявлення загальної динаміки стану галузі та наявного потенціалу системи освіти відповідного фаху.

Насамперед, при вивченні питань, пов'язаних з НТК в УСРР у 1920-х рр. необхідно зважати на те, що їх підготовка в цей період здійснювалася в інститутах, хоча республіканські технікуми теж готували спеціалістів вищої кваліфікації - інженерів, але експлуатаційників [5, с. 72] Внаслідок цього, відомості стосовно роботи українських технікумів упродовж обраного хронологічного відтинку до уваги не бралися. Також, розглядаючи специфіку умов підготовки НТК вітчизняної галузі виробництва електричних машин від моменту встановлення радянської влади в Україні варто взяти до уваги, що в дорадянські часи на українських теренах домінували зарубіжні виробники такої продукції [6, с. 6]. Відповідно до укладеного ними порядку, науковий супровід виробництва на українських промислових потужностях здійснювався 3 центральних конструкторських бюро материнських компаній, розташованих за кордоном, тож в заводських інженерно-технічних кадрах переважав технічний персонал [7, с. 36]. У 1921 р. 3 усіх дореволюційних електромашинобудівних промислових закладів за дореволюційною номенклатурою продукції і з середнім навантаженням у 15-20\% працювали лише «Електросила № 1» у Харкові та Київські електромеханічні майстерні, що не вимагало якісної зміни НТК, а тим паче - їх збільшення [8, с. 80]. До 1923 р., не зважаючи на розгортання в СРСР заходів з електрифікації країни, ситуація із попитом на продукцію 
«Електросили № 1» погіршилася, внаслідок чого союзним урядом було поставлене питання про закриття цього найбільшого в Радянському Союзі електромашинобудівного заводу [9, арк. 1]. Наведений факт свідчить про споконвічну орієнтованість уряду на участь у відповідних заходах ленінградського заводу «Электросила» та іноземних фірм, 3 виключенням 3 даного процесу українського виробника електромашинобудівної продукції, принаймні на первісному етапі. Отже, попри окремі твердження в сучасній історичній науці, які формують уяву стосовно високого рівня розвитку на початку 1920-х рр. в УСРР відповідних дослідницької діяльності та науково-технічного кадрового середовища, мусимо визнати, що в історичній реальності такого не було, оскільки в протилежому випадку питання про закриття «Електросили № 1» на тлі процесу розгортання заходів з виконання грандіозних планів електрифікації країни не піднімалося б [3, арк. 115, 117-121]. Потужний потенціал української електромашинобудівної науковотехнічної спільноти, в разі існування такого бодай у Харкові, був би спроможним запропонувати достатній обсяг конструкцій машин, потрібних для здійснення заходів 3 електрифікації республіки, а також допомогти «Електросилі № 1» 3 освоєнням їх виробництва, чого, однак, не відбулося.

Тим не менш, рішення щодо закриття підприємства ухвалене не було, чому сприяло два чинники, один з яких - відкриття в 1921 р. у Харківському технологічному інституті електротехнічного факультету, що передбачало в майбутньому збільшення притоку науково-технічних фахівців, хоча у 1923-1924 рр. спостерігалося дворазове (до 15 чол.) скорочення випуску спеціалістів електротехнічного фаху [3, арк. 126]. Тож більш важливою причиною для продовження роботи «Електросили № 1» стала модернізація озброєння військово-морських сил (ВМС) СРСР, що тривала з 1922 р. і мала закінчиться в 1926 р. перетворенням у програму будівництва нового підводного флоту. У свою чергу, в період I Світової війни «Електросила № 1» як Харківський електромеханічний завод Російського товариства «Загальна компанія електрики» брав активну участь у виробництві мінно-торпедного озброєння російських ВМС, а також у продукуванні корабельної електротехніки для російських субмарин $[10$, с. 6]. Оскільки проведення модернізації озброєння без залучення його виробника несло ризики подовження та подорожчання цього процесу, «Електросила № 1» був залишений працюючим, хоча й у зовсім незначних обсягах - фактичне виключно на потреби модернізаційної програми, яка сама не мала масштабності у зв'язку із уже вирішеним на другу половину 1920-х рр. переозброєнням BMC CPCP.

На підтвердження, що саме значення «Електросили № 1» у військовій програмі, а не інші чинники, пов'язані з процесом електрифікації, вплинуло на рішення залишити це підприємство працювати, опосередковано свідчить його достатньо скрутний фінансовий стан до початку заходів із створення нових субмарин згідно шестирічної програми розбудови підводного військового флоту в 1927-1932 pp., який підтверджується радянською історіографією [2, с. 45]. Іншими словами, якби українське електромашинобудування розглядалось урядом СРСР як одна 3 рушійних сил розгорнутого в 1921 р. процесу електрифікації радянського суспільства, то факт продовження роботи «Електросили № 1» при тому, що: була закрита решта заводів колишній «Сіменс-Шукерт» та ХЕМЗ російсько-французького товариства в Харкові, «Вікерс» у Катеринославі, можна було вважати заходом, спрямованим на збереження базових потужностей в умовах ще недостатнього попиту на електромашини. Але тоді «Електросила № 1» мав би бути забезпечений замовленнями достатньою мірою для його, бодай, безперебійної роботи, чого не відбулося, і не відбувалося доти, доки на ньому не розпочалося виготовлення силового електрообладнання для субмарин I-ї серії: великих торпедних підводних човнів типу «Ленинец». Хоча до того вже було споруджене Алмазне-Мар'їнське кільце районних електростанцій, а на 1926 р. - перша черга Штерівської електростанції, і це - без урахування центральних заводських електростанцій на кшталт електростанцій Брянського та Кадієвського металургійних заводів [11, 
арк. 130-131]. Тобто, обсяги розгорнутих в Україні робіт з електрифікації промисловості були настільки великими, що у випадку спроможності вітчизняних виробників задовольняти споживчі вимоги до технічного рівня електричних машин, про зупинку українських електромеханічних заводів не могло б йти мови.

Характерним $є$ те, що в цей же час Державним електротехнічним трестом СРСР був укладений «Договор о техническом содействии» 3 колишньою материнською компанією «Електросили № 1»- німецькою «АЕГ» і електрооснащення конструкцій саме цієї фірми, виготовлене «Електросилою № 1» (перейменованим у Державний електромеханічний завод (ДЕЗ) та запущеним у дію, як раз на цей момент, Харківським електротехнічним заводом (ХЕ3) (кол. Сіменс-Шукерт), було встановлене на кораблях згаданої вище серії $[12$, с. 10]. Утім, на цих же заводах у 1926-1927 pp. було налагоджене й виробництво електродвигунів цивільного призначення післявоєнних конструкцій «АЕГ»: постійного струму у діапазоні потужностей від 0,3 до 40 КВт, змінного - від 0,175 до 525 КВт, але при тому, виробництво цієї ж номенклатури продукції передавалося й в концесію шведській «АСЕА» [13]. Іншими словами, наприкінці 1920-х pp. українські електромашинобудівні заводи завантажувалися продукцією як військового, так i цивільного призначення, а на іноземних виробників покладалося виробництво виключно цивільних електричних машин. Даний розподіл говорить про те, що за рахунок масштабного виготовлення на вітчизняних заводах цивільних виробів, окрім міркувань втаємничення розташування воєнного виробництва, передбачалося компенсовувати високу витратність оборонної продукції. Але у зв'язку з відсутністю достатнього рівня наукового супроводу виробничих процесів на українських підприємствах, масовий випуск електромашин загального вжитку потрібної якості організувати було доволі проблематично, що повинно було компенсуватися завдяки продукції іноземних фірм.

Опосередковано, військовий акцепт впливу на розвиток українського електромашинобудування в другій половини 1920-х років підтверджується й тим, що 3 1926 р. згортається підготовка фахівців 3 суднової електротехніки в Одеському політехнічному інституті (ОПІ), проте збільшується контингент студентівелектромашинобудівників (без афішування спеціалізації) у XTI - за місцем розташування iii виробників [14, арк. 6]. До того, підготовлені ОПІ науково-технічні співробітники спрямовувалися, здебільшого, на військово-морські підприємства Миколаєва, Херсона та Севастополя, тобто, за місцем розташування споживачів суднової електротехніки. Таким чином, початок концентрації в Харкові підготовки науково-технічних спеціалістів електромашинобудівного фаху хронологічно повністю співпадає з облаштуванням тут промислового осередку 3 виробництва електричних машин військово-морського призначення в середині 1920-х рр. і трохи випереджає розгортання в місті масового випуску цивільних електромашин.

Отже, заходи уряду з індустріалізації та електрифікації СРСР не стали споконвічною рушійною силою розвитку електромашинобудування на українських теренах у 1920-х pp. Відсутність на початку 1920-х рр. республіканської системи наукового забезпечення українських електромашинобудівних заводів не давала можливості останнім запропонувати споживачам потрібні їм нові електричні машини, що, по суті, до середини 1920-х рр. виключила українське електромашинобудування з числа виконавців указаних вище заходів, попри активну участь в них російських та іноземних підприємств. Проте у другій половині 1920-х рр. у Харкові відновлюється український осередок виробництва електричних машин на грунті зарубіжного наукового забезпечення, при цьому низка опосередкованих історичних фактів підтверджує його первісне військове призначення. Усі вищезазначені чинники склали ті особливості умов підготовки в УСРР у 1920-х рр. науково-технічних спеціалістів електромашинобудівного фаху, що проявилися, насамперед, у перевищенні загального рівня наявних відповідних знань на підприємствах для яких готувалися ці кадри перед самими підготовчими закладами. 


\section{ДЖЕРЕЛА ТА ЛІТЕРАТУРА}

1. История энергетической техники СССР: В 3-х т. / А. Г. Александров и др. Москва-Ленинград, 1957. Т. 2. Электротехника. 728 с.

2. Очерк истории Харьковского электромеханического завода: в 2-х ч. / В. В. Суздальцев и др. Харьков, 1965. Ч. 2. 1918-1964 гг. 260 с.

3. Тверитникова О.С. Внесок учених Харківського технологічного та електротехнічного інститутів у розвиток електротехнічної галузі України (1885-1950рр.): дис.... канд. іст. наук: 07.00.07 / НТУ «ХПІ». Харків, 2009. 267 арк.

4. Тверитникова О.С. Розвиток мережі підготовки кадрів для електротехнічного промислового комплексу // Вісник національного технічного університету «ХПІ». Автоматика та приладобудування. Харків, 2007. № 37. С. 90-93.

5. Бейлин А.Е. Кадры специалистов СССР: их формирование и рост. Москва: Союзоргучет, 1935. $420 \mathrm{c}$.

6. Аннєнков I.О. Електромашинобудування на українських теренах Росії напередодні революційних потрясінь та громадянської війни $(1917$ р.) // Історія науки і біографістика. 2014. № 2. C. 1-16. URL: http://inb.dnsgb.com.ua/2014-2/index.html

7. Анненков И.А. Определение уровня научного обеспечения производства на заводе Русского Общества «Всеобщая компания электричества» в 1915-1918 гг. посредством номенклатурного анализа выпускаемой продукции // Вестник Томского университета. История. Томск, 2014. № 5 (31). С. 33-38.

8. Васильев М.П., Тейтель И.В., Потресов В.Е. Промышленность Украины в 1921 году. Харків: УСНХ, 1922. 200 с.

9. Довідка про політичний стан у Петінському районі м. Харкова за березень 1923 p. // Державний архів Харківської області. Ф. П-1. Оп. 1. Спр. 896. Арк. 1-2 зв.

10. Аннєнков I.O. Проект Миколаївського трубкового та електромеханічного заводу: задум і реалізація (1915-1918 рр.) // Вісник національного технічного університету «ХПІ». Історія науки і техніки. Харків, 20013. № 68. С. 3-8.

11. Тезисы докладов, обзоры, информации, итоговые материалы ВСНХ, наркоматов республики в ЦК КП(б)У за 1925 г. о состоянии и перспективах развития промышленности Украины //) Центральний державний архів громадських об'єднань України (далі - ЦДАГО України). Ф. 1. Оп. 20. Спр. 2034. 145 арк.

12. Новиков М.В. Иностранный капитал в советской электротехнической промышленности сильных токов: формы привлечения и результаты использования (19201932 гг.): автореф. дис. ... канд. эконом. наук: 08.00.01 «Экономическая теория» / Волгоградский государственный університет. Волгоград, 2006, 21 с.

13. Лист № 47 с. Правління Харківського відділення Державного електротехнічного тресту до Секретаря ЦК КП(б)У від 03.01.1927 р. // ЦДАГО України. Ф. 1. ОП. 20. Спр. 2506. Арк. 2-3.

14. Доклады о деятельности Одесского политехнического института в 1927 г. // Державний архів Одеської області. Ф. Р-126. Оп. 1. Спр. 407. 71 арк.

\section{REFERENCES}

1. Aleksandrov, A.G. i dr. (1957). Istoriya energeticheskoj tekhniki SSSR: V 3-kh t. [The history of energy techniques of the USSR]. Moskva-Leningrad: Gosenergoizdat. T. 2. Elektrotekhnika [in Russian].

2. Suzdal'czev, V. i dr. (1965). Ocherk istorii Kharkovskogo elektromekhanicheskogo zavoda: V 2-kh ch. [The history of the Kharkov electromechanical plant]. Kharkov: Prapor. Ch. 2. 1918-1964 gg. [in Russian].

3. Tverytnykova, O.Ye. (2009). Vnesok uchenyx Kharkivskogo tekhnologichnogo ta elektrotekhnichnogo instytutiv u rozvytok elektrotekhnichnoyi galuzi Ukrayiny (1885-1950 rr.) [Contribution of scientists of the Kharkov Technological and Electrotechnical Institutes to the 
development of the electrotechnical industry of Ukraine (1885 - 1950)]: dys... kand. ist. nauk: 07.00.07 / NTU «KhPI». Kharkiv [in Ukrainian].

4. Tverytnykova, O.Ye. (2007). Rozvytok merezhi pidgotovky kadriv dlya elektrotekhnichnogo promyslovogo kompleksu [Development of a training system for the electrical industry]. Visnyk nacional nogo tekhnichnogo universytetu «KhPI». Avtomatyka ta pryladobuduvannya. Kharkiv, 37. [in Ukrainian].

5. Bejlin, A.E. (1935). Kadry speczialistov SSSR: ikh formirovanie i rost [Personnel of the USSR specialists: their formation and growth]. Moskva: Soyuzorguchet [in Russian].

6. Annyenkov, I.O. (2014). Elektromashynobuduvannya na ukrayins`kykh terenakh Rosiyi naperedodni revolyucijnykh potryasin` ta gromadyans`koyi vijny (1917 r.) [Electric machinery industry on the Ukrainian lands of Russia on the eve of revolutionary upheavals and civil war (1917)]. Istoriya nauky i biografistyka - History of Science and Biography, 2. URL: http://inb.dnsgb.com.ua/2014-2/index.html [in Ukrainian].

7. Annenkov, I.A. (2014). Opredelenie urovnya nauchnogo obespecheniya proizvodstva na zavode Russkogo Obshhestva «Vseobshhaya kompaniya elektrichestva» v 1915-1918 gg. posredstvom nomenklaturnogo analiza vypuskaemoj produkczi. [Determining the level of scientific support for production at the plant of the Russian society "General Electricity Company" in 1915-1918 using the method of nomenclature analysis of products]. Vestnik Tomskogo universiteta. Istoriya - The Tomsk University Herald. History, 5 (31) [in Russian].

8. Vasilev, M.P., Tejtel', I.V. \& Potresov, V.E. (1922). Promyshlennost Ukrainy $v$ 1921 godu [Industry of Ukraine in 1921]. Kharkiv: USNKh [in Russian].

9. Dovidka pro politychnyj stan u Petins`komu rajoni m. Kharkova za berezen` $1923 \mathrm{r}$. [The reference of the political situation in the Petinsky district of the city of Kharkov for March 1923] // DAKhO - State Archive of Kharkov region. Fund R-1. Description 1. Case 896. pp. 1-2 [in Russian].

10. Annyenkov, I.O. (1913). Proekt Mykolayivs`kogo trubkovogo ta elektromekhanichnogo zavodu: zadum i realizaciya (1915-1918 rr.) [The project of the Nikolaev plant of detonating fuse and electromechanical products: plans and implementation (1915-918)]. Visnyk nacional nogo tekhnichnogo universytetu "KhPI». Istoriya nauky i tekhniky - Bulletin of the National Technical University "KhPI". History of Science and Technology, 68. Kharkiv [in Ukrainian].

11. Tezisy dokladov, obzory, informaczii, itogovye materialy VSNKh, narkomatov respubliki v CzK KP(b)U za 1925 g. o sostoyanii i perspektivakh razvitiya promyshlennosti Ukrainy [Abstracts, reviews, information, final materials of the Supreme Economic Council, the people's commissariats of the republic into the CC of the $\mathrm{CP}(\mathrm{b})$ of Ukrain for 1925 on the state and prospects of industrial development of Ukraine] // TsDAHO Ukrayiny - Central State Archive of public unions of Ukraine. Fund 1. Description 20. Case 2034. 145 p. [in Russian].

12. Novikov, M.V. (2006). Inostrannyj kapital v sovetskoj elektrotekhnicheskoj promyshlennosti sil nykh tokov: formy privlecheniya i rezul taty ispol zovaniya (1920-1932 gg.) [Foreign capital in the Soviet electrical industry of high currents: forms of attraction and results of use (1920-1932)]: avtoref. dis.... kand. ekonom. nauk: 08.00.01 «Ekonomicheskaya teoriya» / Volgogradskij gosudarstvennyj uni versitet. Volgograd [in Russian].

13. Ly`st Pravlinnya Xarkivs`kogo viddilennya Derzhavnogo elektrotexnichnogo trestu do Sekretarya CzK KP(b)U vid 03.01.1927 r. [Letter from the board of the Kharkiv branch of the State Electrotechnical Trust to the Secretary of the CC of the CP (b) of Ukraine of 03/03/1927. №47] // TsDAHO Ukrayiny - Central State Archive of public unions of Ukraine. Fund 1. Description 20. Case 2506. Pp. 2-3 [in Russian].

14. Doklady o deyatel'nosti Odesskogo politekhnicheskogo instituta v $1927 \mathrm{~g}$. [Reports on the activities of the Odessa Polytechnic Institute in 1927] // DAOO - State Archive of Odesa region. F. R-126. Op. 1. Spr. 407. 71 ark. [in Russian]. 